\title{
Editorial - Transformations of Latin American Catholicism Since the Mid-20th Century
}

\author{
Renata Siuda-Ambroziak ${ }^{1,2} \cdot$ Rodrigo Coppe Caldeira $^{3}$
}

Published online: 15 November 2021

(c) The Author(s), under exclusive licence to Springer Nature Switzerland AG 2021

This issue includes a selection of articles focusing on changes in Latin American Catholicism from the mid-twentieth century onwards caused by a variety of factors of cultural, social, political, and economic nature, which had a profound impact on the subcontinent's religious panorama. One key-element is the pluralization of the religious field. Other aspects have to do with political changes, economic turbulences, social upheavals, and cultural transformations. All these factors have reshaped the profile of Latin American Catholicism indicated by the rise of new Catholic movements, theological approaches, and religious experiences.

The analyses of this constellation must consider the significant impulses generated by the Second Vatican Council. The conciliar event convoked by Pope John XXIII turned out to be a fundamental landmark for global Catholicism in the twentieth century, and, consequently, for its numerous expressions in Latin America that have legitimized and encouraged innovative ways for Catholics to interpret and approach the social realities of their respected countries. From the standpoint of theology, there has been a change from an ecclesiology-based ahistorical concept of a church as distant from the "outer" world to an understanding of its communion with the world. At the same time, the Church in Latin America started redefining its political position in detriment of an alliance with the political establishment, and in favor of a deeper sensibility for the people and their struggle for social change. The most important consequence of this paradigm-shift was the emergence of the Liberation Theologies and the Ecclesial Base Communities.

Obviously, the rise of "progressive" Catholicism characterized by an active participation in social matters and an - sometimes too close - involvement with ideologies and politics has challenged a series of conventional assumptions about the

Renata Siuda-Ambroziak

r.siuda@uw.edu.pl

Rodrigo Coppe Caldeira

rodrigocoppe@gmail.com

1 University of Warsaw (UW), Warsaw, Poland

2 Rio de Janeiro State University (UERJ), Rio de Janeiro, Brazil

3 Pontifícia Universidade Católica de Minas Gerais (PUC MG), Belo Horizonte, Minas, Brazil 
church and its status, role, and functions in Latin America. However, such a situation also provoked direct responses of right-wing movements and parties, as well as of traditional and orthodox movements.

Aspects such as the vivacity and dynamism of Catholic religious expressions in the subcontinent, the relations between its agents and the socio-political substrata, or the emergence of the first pontiff from the region have enhanced the interests of researchers in Latin American Catholicism. The ten articles included in the thematic session, while not necessarily reflecting the point of view of the guest editors on the described matters, certainly reflect this growing academic attention.

The manuscripts have been divided into two groups. The first one focuses on Catholic practices (individual and collective), as well as on popular religiosity traditions and rituals in contemporary Latin America. The second one refers to contemporary changes in institutional Catholic Church, in terms of religious leaders, ministry, theology, and socio-political involvement.

The inaugurating article of the first group "Andino-Catholic Rituals in Automobile Bolivia: Bendiciones, Ch'allas and K'oas performed by Drivers from Chuquisaca" - submitted by Manuel Moser - explores various rituals in the Bolivian region of Chuquisaca. The article reveals two different trends in contemporary Bolivian Catholicism uphold or by the clergy or by common devotees. From the perspective of the participants in the vehicle-blessing, the latter are in tune with the Catholic faith although the rituals are complemented by rituals performed by local "curanderos" and criticized by the clergy.

In the second article, entitled "Contemporary Transformations in the Brazilian Popular Catholic Festivals: the Case of the Holy Divine Spirit Festival (Festa do Divino)", Renata Siuda-Ambroziak and Fabiene Passamani Mariano discuss modifications of centuries old traditional Catholic festivals in Brazil. For the authors, the changes of the Divine Holy Spirit Festivals reflect local conflicts as well as more general sociocultural shifts, political disputes, and religious changes. Against this background, the article argues that the festivals have contributed to the maintenance of close community relationships, despite the impact of secularization, consumerism, mass culture, and the predominance of economically feasible solutions of daily problems of the local people.

In "Catholicism in Day-to-Day Life in Argentina During a Pandemic Year: Blurring the Institutional Boundaries", Verónica Giménez Béliveau focuses on individual Catholic practices carried out at home during the pandemic lockdown. She shows how domestic surroundings have been sacralized by blessed objects (domestic altars, images, and holy cards) making a believer's home the center of everyday religious practices. Verónica Giménez Béliveau then problematizes the effects caused by the believers' isolation in their private settings and the substitution of personal encounters by communication through online-platforms. On the other hand, the social media and virtual spaces offer new possibilities indicated by the increasing popularity of two different Catholic communities, that is, the revivalist Ministry of Awakening and the Blessed Angelelli and the Companions in Martyrdom chapel.

The article "Nobody Prays Alone: The Practice of Prayer Among Catholics in Three Latin American Cities", submitted by Gustavo Morello, considers prayer not only as a means of connecting with God but, seen from a sociological standpoint, 
also as a social activity that allows the individual to engage in various webs of human relations. In this sense, even if prayer seems to be personal, its meanings and performative styles are socially constructed.

Ole Jakob Løland's essay "The Solved Conflict: Pope Francis and Liberation Theology" inaugurates the second group of articles. It deals with the changing relationship between Latin American liberation theologians and the Vatican, noticeable after the election of Jorge Mario Bergoglio as head of the Catholic Church. The author argues that, despite the canonization of Archbishop Oscar Romero and the Pope's approximation to some of the outstanding "liberationists", Francis remains an outsider to the movement. His role is restricted to easing the conflict through symbolic gestures rather than through a theological shift or intellectual debates. Thus, the author judges the common idea that Pope Francis is a political leftist, or even a radical reformer and revolutionary, as an exaggeration.

The article submitted by João Décio Passos (Pope Francis: Updating Puebla in the Era of Conciliar Aggiornamento) points in another direction. The author emphasizes Pope Francis' contribution to the hermeneutical reception of the documents promulgated at the Puebla Conference in terms of a conciliation between the tradition of the universal Catholic Church and the ecclesiastic and theological concerns specific for Latin America.

In "Religious Sisters in Latin America. Identity, Challenges, and Perspectives," Ana Lourdes Suárez and Veronique Lecaros offer a comparative analysis of the life and ministry of women in Latin America from 1970 to 2017. The authors present information and data regarding aspects such as the social and ecclesial identity of the religious sisters, recent theological trends, including the role of feminist theologies, their position within Latin American societies, as well as possible reasons for the decreasing number of feminine vocations.

Rodrigo Coppe Caldeira and Emerson José Sena da Silveira, authors of "Catholic Church and Conservative-Traditionalist Groups: The Struggle for the Monopoly of Brazilian Catholicism in Contemporary Times," comment on the traditionalist movements and groups in the Brazilian Catholic Church. The authors argue that traditionalist and conservative tendencies are not restricted to organizations such as the Brazilian Society for the Defense of Tradition, Family and Property, the Associação Cultural Monfort or the Heralds of the Gospels but can also be identified within Brazil's Catholic charismatic renewal-movement.

In her article "From the Preferential Option for the Poor to Conservative Catholicism: The History of the Diocese of Cuernavaca as a Field," Cecilia DelgadoMolina addresses the transformations in Catholicism within the Cuernavaca Diocese in Mexico from 1952 to 2013. The author gives an overview of different expressions of popular religion and discusses significant transformations within Latin American Catholicism, including a stronger emphasis on solidarity with the poor, the upsurge of emotional religiosity, but also the emergence of conservative tendencies.

Last, but not least, the article "The Current Political Path of an Ultra-Catholic Agent of Brazilian Christofacism Father Paulo Ricardo," written by Fabio Py, addresses the biography, political and religious trajectory, as well as the recent role of the Brazilian Catholic priest Paulo Ricardo's in the latest political history of Brazil, namely for the mobilization of President Bolsonaro's rightwing supporters by 
means of the social media. According to the hypothesis that any activity of Father Paulo Ricardo can be considered a political action in favor of the current federal government, the author analyzes his object in terms of the concept of "Christofascism."

Publisher's Note Springer Nature remains neutral with regard to jurisdictional claims in published maps and institutional affiliations. 